\title{
Biological effect of ketamine in urothelial cell lines and global gene expression analysis in the bladders of ketamine-injected mice
}

\author{
CHENG-HUANG SHEN ${ }^{1 *}$, SHOU-TSUNG WANG ${ }^{2,3^{*}}$, YING-RAY LEE $^{4,5}$, SHIAU-YUAN LIU $^{2}$, \\ YI-ZHEN LI ${ }^{2}$, JIANN-DER WU ${ }^{6}$, YI-JU CHEN ${ }^{6}$ and YI-WEN LIU ${ }^{2}$
}

\begin{abstract}
Departments of ${ }^{1}$ Urology, Chiayi Christian Hospital, ${ }^{2}$ Microbiology, Immunology and Biopharmaceuticals, College of Life Sciences,
${ }^{3}$ Food Science, National Chiayi University and ${ }^{4}$ Medical Research, Chiayi Christian Hospital, Chiayi 600; ${ }^{5}$ Department of Nursing, Min-Hwei College of Health Care Management, Tainan 73658;

${ }^{6}$ Department of Pathology, Chiayi Christian Hospital, Chiayi 600, Taiwan, R.O.C.
\end{abstract}

Received December 14, 2013; Accepted June 17, 2014

DOI: $10.3892 / \mathrm{mmr} .2014 .2823$

\begin{abstract}
Ketamine is used clinically for anesthesia but is also abused as a recreational drug. Previously, it has been established that ketamine-induced bladder interstitial cystitis is a common syndrome in ketamine-abusing individuals. As the mechanisms underlying ketamine-induced cystitis have yet to be revealed, the present study investigated the effect of ketamine on human urothelial cell lines and utilized a ketamine-injected mouse model to identify ketamine-induced changes in gene expression in mice bladders. In the in vitro bladder cell line assay, ketamine induced cytotoxicity in a dose- and time-dependent manner. Ketamine arrested the cells in G1 phase and increased the sub-G1 population, and also increased the barrier permeability of these cell lines. In the ketamine-injected mouse model, ketamine did not change the body weight and bladder histology of the animals at the dose of $30 \mathrm{mg} / \mathrm{kg} /$ day for 60 days. Global gene expression analysis of the animals' bladders following data screening identified ten upregulated genes and 36 downregulated genes induced by ketamine. A total of $52 \%$ of keratin family genes were downregulated, particularly keratin 6a, 13 and 14, which was confirmed by polymerase chain reaction analysis. Keratin 14 protein, one of the 36 ketamine-induced downregulated genes, was also reduced in the ketamine-treated mouse bladder, as determined by immunohistochemical analysis. This suggested
\end{abstract}

Correspondence to: Professor Yi-Wen Liu, Department of Microbiology, Immunology and Biopharmaceuticals, College of Life Sciences, National Chiayi University, 300 Syuefu Road, Chiayi 600, Taiwan, R.O.C.

E-mail: ywlss@mail.ncyu.edu.tw

${ }^{*}$ Contributed equally

Abbreviations: FBS, fetal bovine serum; H\&E, hematoxylin and eosin; PI, propidium iodide; RNase A, ribonuclease A

Key words: bladder, cytotoxicity, gene expression profiling, ketamine, keratin that cytotoxicity and keratin gene downregulation may have a critical role in ketamine-induced cystitis.

\section{Introduction}

Ketamine was first synthesized in 1962 (1) and introduced into clinical medicine for dissociative anesthesia in 1970 (2). It is a non-competitive $N$-methyl-D-aspartic acid receptor antagonist and used as a short-acting general anesthetic in human and veterinary clinical settings (3). Due to its low cost and the fact that it induces hallucination and alters the state of consciousness, ketamine soon emerged as a recreational drug (4). As the number of ketamine abusers gradually increased, a new side effect on the bladder was first reported in $2007(5,6)$. The symptoms of ketamine-induced cystitis include dysuria and urgency $(7,8)$, and cystoscopic examination of severe cases demonstrated hemorrhagic cystitis, denuded mucosa and marked inflammation (9). The symptoms are similar to interstitial cystitis (IC) (6), therefore, certain treatment regimens, including oral pentosan polysulphate and intravesical instillation of hyaluronic acid, are used in ketamine-induced cystitis, to relieve the varying degrees of symptoms $(6,9,10)$. Other medicines, including antibiotics, non-steroidel anti-inflammatory drugs, steroid and anticholinergic drugs, are also applied for therapy, but the benefit is limited (9).

To date, no specific treatment for patients with ketamine-induced cystitis has been established. In spite of the increase in the number of recreational users, investigating ketamine-induced cystitis in humans is not simple. As a result, a number of studies have used animal models for investigating the mechanisms of action and effects of ketamine. Previously, to the best of our knowledge, two mouse model $(11,12)$ and two rat model $(13,14)$ in vivo studies have been published. In Yeung et al's mouse model (11), $30 \mathrm{mg} / \mathrm{kg} / \mathrm{day}$ ketamine injection induced submucosal infiltration of mononuclear inflammatory cells. The urothelium became thinner and the number of nerve fibers was reduced following one month of ketamine treatment. In Meng's mouse study (12), following $100 \mathrm{mg} / \mathrm{kg} /$ day ketamine injection for 2 4 months, a decrease in the mouse body weight growth rate and bladder capacity, 
the increase of adenosine triphosphate-evoked detrusor contraction and $\mathrm{P} 2 \mathrm{X} 1$ receptor protein was observed in the animal bladders. In Gu's rat model (13), the whole rat bladder proteins were analyzed by two-dimensional electrophoresis following $50 \mathrm{mg} / \mathrm{kg} /$ day ketamine injection for four months. The bladder histological examination demonstrated hyperplastic urotheliums and inflammatory cell infiltration. The phosphorylated transgelin of bladder smooth muscle was increased by ketamine treatment, which suggested that transgelin may have a role in decreasing bladder contractility. In Chuang's rat study (14), it was revealed that $25 \mathrm{mg} / \mathrm{kg} / \mathrm{day}$ ketamine injection for one month induced cyclooxygenase-2 and inducible nitric oxide synthase gene expression in the rat bladders.

Although the animal studies mentioned above provided notable insight into the mechanisms of ketamine-induced bladder damage, these effects remain to be fully elucidated. In the present study, three urothelial cell lines were used to study the cytotoxicity of ketamine and the barrier permeability affected by ketamine. In the in vivo assay, a mouse animal model was designed for global gene expression analysis in the bladders.

\section{Materials and methods}

Cell culture and ketamine treatment. Three different urothelial cell lines, purchased from Bioresource Collection and Research Center (Hsinchu, Taiwan) were used. The SV-HCU-1 cell line derived from normal human urothelial cells immortalized by the SV40 virus. The RT4 cell line is derived from a well-differentiated papillary tumor of the human bladder (15). The 5637 cell line is a grade II carcinoma of the human bladder (16). SV-HUC-1 cells were cultured in Ham's F-12 medium (Gibco Life Technologies, Grand Island, NY. USA) supplied with $7 \%$ fetal bovine serum (FBS; Biological Industries, M.P. Ashrat, Israel). RT4 cells were cultured in McCoy's 5A medium (Sigma-Aldrich, St. Louis, MO, USA) supplied with $10 \%$ FBS, $1 \%$ penicillin and $1 \%$ streptomycin. 5637 cells were maintained in RPMI-1640 medium (Gibco Life Technologies) supplied with $10 \% \mathrm{FBS}, 1 \%$ penicillin and 1\% streptomycin (Gibco Life Technologies). The cells were incubated in a $\mathrm{CO}_{2}$ incubator at $37^{\circ} \mathrm{C}$, with $5 \% \mathrm{CO}_{2}$ and 95\% filtered air. Ketamine (Sigma-Aldrich) was dissolved in normal saline. For the cultured cell assay, ketamine was added to cells of the ketamine-treated groups, while the same volume of normal saline was added to the control cells.

Cell viability assay. The cell number was determined by a colorimetric MTT assay. The cells were seeded in 96-well plates for $24 \mathrm{~h}$, then were incubated with various concentrations of ketamine or normal saline for another 24-48 h. MTT was added into the medium for $2 \mathrm{~h}$, then the medium was discarded and dimethyl sulfoxide was added to dissolve the formazan product. Each well was measured by light absorbance at $490 \mathrm{~nm}$. The result was expressed as the percentage of the normal saline-treated control group.

Cell cycle analysis. The cells were seeded in 100-mm dishes. Following $24 \mathrm{~h}$ incubation, ketamine or normal saline was added. Following treatment for 24 and $48 \mathrm{~h}$, the cells were trypsinized, centrifuged at $800 \mathrm{x}$ g for $5 \mathrm{~min}$ and fixed with ice-cold $75 \%$ ethanol overnight at $4^{\circ} \mathrm{C}$. Following removal of the ethanol, the cells were stained with a DNA staining solution [containing $1 \mathrm{mg} / \mathrm{ml}$ propidium iodide and $10 \mathrm{mg} / \mathrm{ml} \mathrm{RNase} \mathrm{A}$ dissolved in phosphate-buffered saline (PBS)] for $30 \mathrm{~min}$ at room temperature. The DNA content of the stained cells was measured using a FACScan flow cytometer. The cell doublets were removed by gating the left area of the FL2-W/FL2-A plot for analysis. The cell cycle data from flow cytometry were analyzed using ModFit LT ${ }^{\mathrm{TM}}$ software (Verity Inc. Sunnyvale, CA).

Urothelial barrier function assay. Approximately $4 \times 10^{4}$ SV-HUC-1 cells, 4x10 4 RT4 cells and $1 \times 10^{4} 5637$ cells were seeded on an Transwell insert with $0.4 \mu \mathrm{m}$ pore size filter membrane (Millipore Corp. Billerica, MA, USA) and incubated for $24 \mathrm{~h}$. Ketamine was added into the upper and lower chamber media at the same time. Following incubation for 19 or $43 \mathrm{~h}$, green fluorescence-labeled antibodies (Alexa Fluor ${ }^{\circledR} 488$ goat anti-mouse immunoglobulin G; Invitrogen Life Technologies) were added into upper chamber medium (9.6 $\mu \mathrm{g}$ /insert) and continued incubating for another $5 \mathrm{~h}$. The total medium in the upper and lower chambers were collected for fluorescence analysis by a fluorescence microplate reader (excitation/emission: 488/519 $\mathrm{nm}$ ).

Animals and ketamine treatment. Six-week-old male Balb/c mice were used in the present study and purchased from the National Laboratory Animal Center (Taipei, Taiwan). All of the animals were maintained at the qualified animal care facility of Biotechnology and Health Hall in National Chiayi University (Chiayi City, Taiwan, R.O.C) for one week prior to intraperitoneal (i.p.) injection. At seven weeks of age, the mice were divided into four groups (12 mice/group), including control-30 days (i.p. normal saline for 30 days), ketamine-30 days (i.p. $30 \mathrm{mg} / \mathrm{kg} /$ day ketamine for 30 days), control-60 days (i.p. normal saline for 60 days) and ketamine- 60 days (i.p. $30 \mathrm{mg} / \mathrm{kg}$ day ketamine for 60 days). The mice were housed in polycarbonate cages, provided with food and water ad libitum and maintained on a $12 \mathrm{~h}$ light-dark cycle at $22 \pm 2{ }^{\circ} \mathrm{C}$. All of the experiments were approved by the Institutional Animal Care and Use Committee of National Chiayi University.

Bladder tissue collection and hematoxylin and eosin staining. Following the 30- or 60-day treatment, the mice were euthanized and the bladder tissues were removed. A total of 20 bladders (five/group) were fixed in $10 \%$ neutral formalin for histological examination, three bladders/group were homogenized together and RNA was extracted, and the other bladders were stored under liquid nitrogen for future use. The bladder tissues in $10 \%$ neutral formalin were embedded in paraffin and then cut into 4- $\mu \mathrm{m}$ sections on glass slides. One slide from each mouse was stained with hematoxylin and eosin (H\&E). Other slides were prepared for immunohistochemical analysis.

Global gene expression analysis. Total RNA was isolated from three bladders in each group using TRIzol reagent (Invitrogen Life Technologies) according to the manufacturer's instructions. The quality of RNA was examined using Agilent's RNA 
A

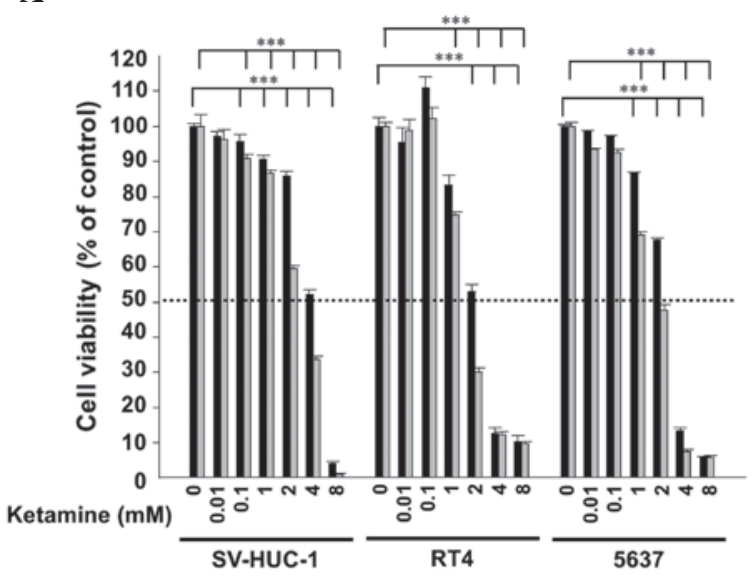

C

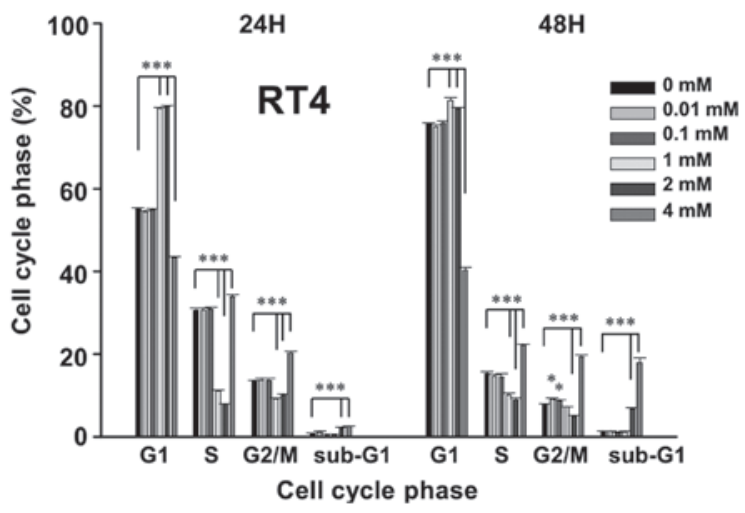

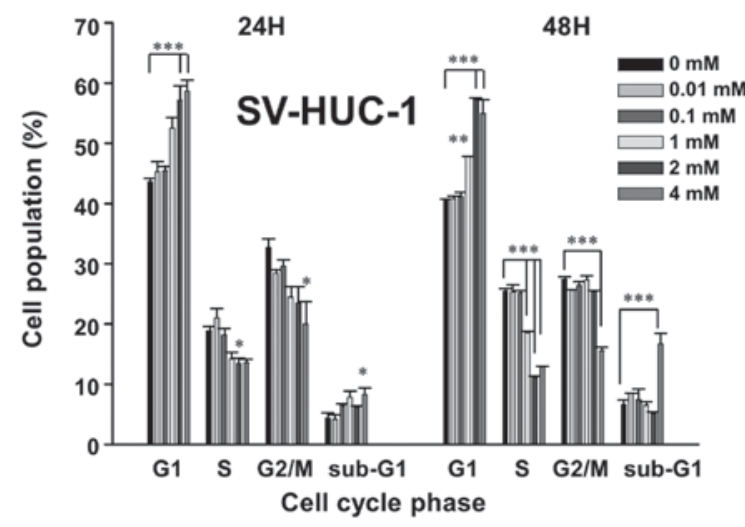

D

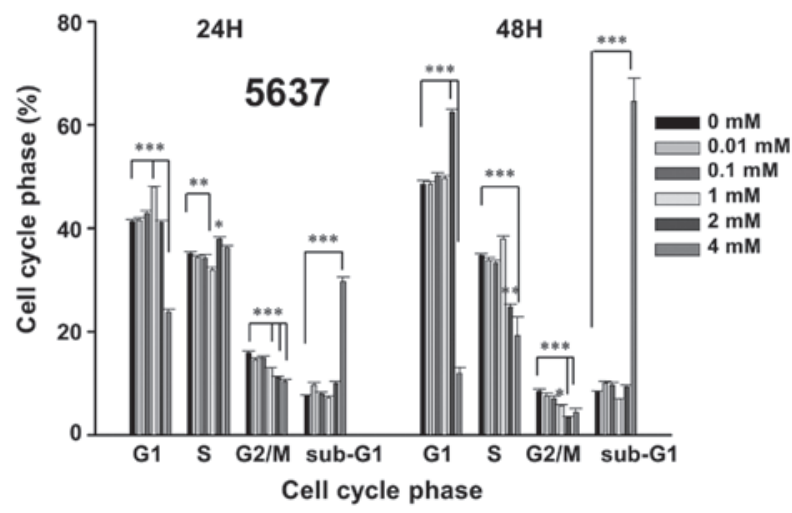

Figure 1. Cytotoxicity of ketamine on SV-HUC1, RT4 and 5637 cells. (A) Cytotoxicity of 0-8 mM ketamine. The cells were treated with 0-8 mM ketamine for $24 \mathrm{~h}$ (black bar) and $48 \mathrm{~h}$ (gray bar), and the cell viability was analyzed by an MTT assay. (B-D) Cell cycle distribution changed following incubation with $0-4$ mM ketamine for 24 and $48 \mathrm{~h}$. The cells were collected for cell cycle analysis following ketamine treatment in (B) SV-HUC1, (C) RT4 and (D) 5637 cells. Quantification performed from three independent experiments. ${ }^{*} \mathrm{P}<0.05,{ }^{* *} \mathrm{P}<0.01,{ }^{* * *} \mathrm{P}<0.001$, significant difference between the control and ketamine-treated cells.

LabChip kits on the 2100 Bioanalyzer (Agilent Technologies, Inc., Santa Clara, CA, USA). The RNA samples from the four groups (control-30 days, ketamine-30 days, control-60 days and ketamine-60 days) were transferred to fluorescence-labeled antisense (a)RNA using OneArray Amino Allyl aRNA Amplification kit (Phalanx Biotech Group, Hsinchu, Taiwan) and Cy5 dye labeling (Amersham Pharmacia, Piscataway, NJ, USA). For global gene expression analysis, the fluorescent targets were hybridized to the Mouse Whole Genome OneArray $^{\mathrm{TM}}$ version MOA 2.0 (Phalanx Biotech Group), containing 27,295 mouse genome probes. One mixture sample was applied to two chips, and the normalized intensities were calculated from raw intensities by median scaling. Microarray image scanning and data analysis were achieved by Phalanx Biotech Group.

Polymerase chain reaction (PCR) analysis. Reverse transcription was performed on $2 \mu \mathrm{g}$ of total RNA by $5 \mu \mathrm{M}$ random hexamer and RevertAid ${ }^{\mathrm{TM}}$ reverse transcriptase (Thermo Fisher Scientific, Fermentas, Pittsburgh, PA, USA), then $1 / 10$ volume of reaction mixture was used for PCR with specific primers (keratin 6a forward 5'-TGCCAGGGGCAAGCTGGAAG-3' and reverse 5'-ACGGGATTCTGCAGCCATGACA-3'; keratin 13 forward 5'-AGCTTGGAGGAGGCCGTAAT-3' and reverse 5'-AAGCACTGTAGTCCCGCTCT-3'; keratin 14 forward 5'-TGGTGCAGAGCGGCAAGAGTG-3' and reverse 5'-TGCGGATCTGGCGGTTGGTGG-3') and $\beta$-actin forward 5'-CCTAAGGCCAACCGTGAAAAG-3' and reverse 5'-TCTTCATGGTGCTAGGAGCCA-3'). The PCR products (keratin 6a, 486 bp; keratin 13, 375 bp; keratin 14, $399 \mathrm{bp}$; $\beta$-actin, 623 bp) were analyzed by $1 \%$ agarose gel.

Immunohistochemical analysis. After being washed in PBS, the slides were incubated in a blocking solution for 30 min and then with primary antibodies against keratin 14 (Genetex, Taipei, Taiwan) at a 1:100 dilution at $4^{\circ} \mathrm{C}$ overnight. The slides were then washed and incubated with secondary antibodies containing horseradish peroxidase at $25^{\circ} \mathrm{C}$ for $30 \mathrm{~min}$. Following this treatment, the slides were washed with PBS and further incubated with 3,3'-diaminobenzidine for $5 \mathrm{~min}$. Finally, the sections were rinsed in running water, treated with hematoxylin for $\sim 10-15 \mathrm{sec}$ and mounted for evaluation.

Statistical analysis. Numerical data (except gene expression microarray data) are expressed as the mean \pm standard error. Statistical differences were analyzed by one-way analysis of 


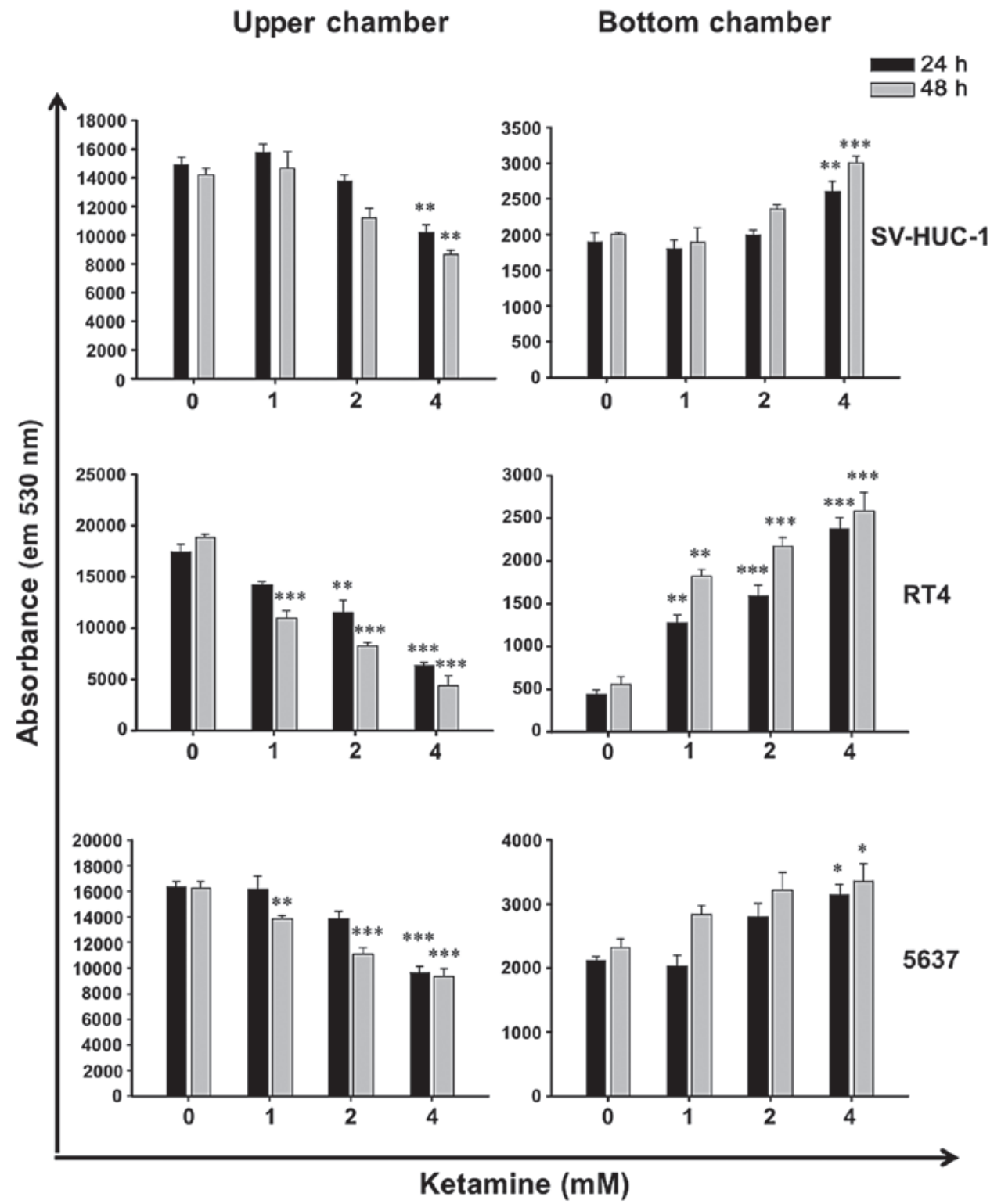

Figure 2. Ketamine increases urothelium barrier permeability in SV-HUC1, RT4 and 5637 cells. The cells were treated with $0-4 \mathrm{mM}$ ketamine for 24 or $48 \mathrm{~h}$, then the upper and bottom chamber media were incubated with Alexa Fluor ${ }^{\circledR} 488$ goat anti-mouse immunoglobulin $\mathrm{G}$ and analyzed by a fluorescence microplate reader. Data are presented as the mean \pm standard deviation of three independent experiments. ${ }^{*} \mathrm{P}<0.05,{ }^{{ }^{* *} \mathrm{P}}<0.01,{ }^{* * * *} \mathrm{P}<0.001$, significant difference between the control and ketamine-treated cells.

variance analysis of variance followed by Tukey's test. All statistics were calculated using SigmaState version 3.5 (Systat Software, San Jose, CA, USA)

\section{Results}

Cytotoxicity of ketamine in human urothelial cell lines SV-HUC-1, RT4 and 5637. Following ketamine treatment for $24 \mathrm{~h}$, the $\mathrm{IC}_{50}$ value of ketamine was $\sim 4,2$ and $3 \mathrm{mM}$ in SV-HUC-1, RT4 and 5637 cells, respectively. At $48 \mathrm{~h}$, the $\mathrm{IC}_{50}$ was $\sim 3,1.5$ and $2 \mathrm{mM}$ in the SV-HUC-1, RT4 and 5637 cells, respectively (Fig. 1A). These results suggested that ketamine is cytotoxic to urotheliums in a dose-dependent and time-dependent manner. Due to the identified cytotoxicity, ketamine-induced cell cycle changes were analyzed. In the SV-HUC-1 cells, ketamine dose-dependently increased the G1 phase cells at a dose higher than $1 \mathrm{mM}$ and significantly increased the sub-G1 level at $4 \mathrm{mM}$ (Fig. 1B). In the RT4 (Fig. 1C) and 5637 (Fig. 1D) cells, ketamine also arrested the cells in the G1 phase between 1 to $2 \mathrm{mM}$, and significantly increased the sub-G1 level at $4 \mathrm{mM}$. All of the above data suggested that ketamine induced G1 arrest and cytotoxicity in the human urothelial cells.

Ketamine increases barrier permeability of human urothelial cells. Due to the cytotoxicity of ketamine (Fig. 1), it was hypothesized that ketamine may decrease epithelial barrier function. Therefore, the urothelial barrier permeability assay was employed. Following ketamine treatment for 24 and $48 \mathrm{~h}$, the permeability of green fluorescence-labeled antibodies was increased dose-dependently in SV-HUC-1, RT4 and 5637 cells (Fig. 2). When comparing the cytotoxicity of ketamine and its enhancing effect on the barrier permeability, it was evident that the dose causing cytotoxicity accompanied 
A

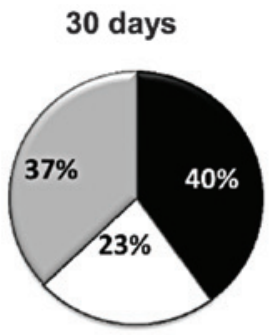

Downregulated gene

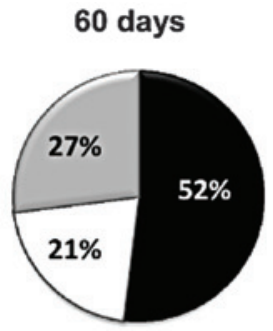

Upregulated gene

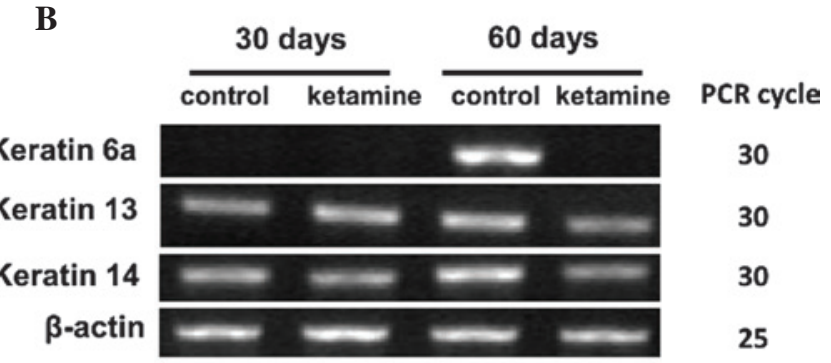

30 days

C

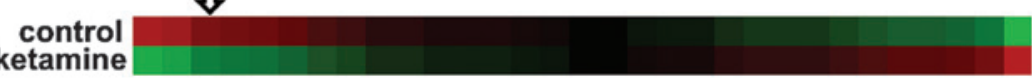

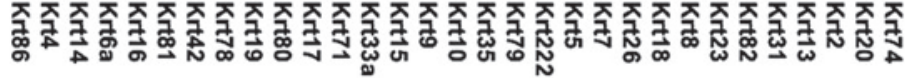

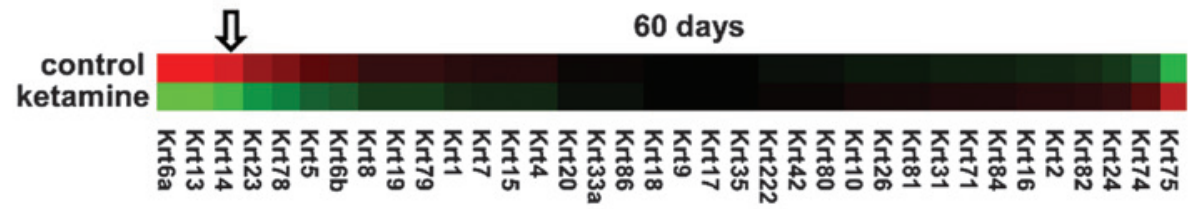

Figure 3. Comparison of keratin family gene expression in the control and ketamine-treated mouse bladders. (A) The pie chart of keratin family genes reveals the percentage of downregulated, upregulated and ND keratin genes. (B) Polymerase chain reaction analysis of three keratin gene expression. The RNA was extracted from mouse bladders following normal saline (control) or $30 \mathrm{mg} / \mathrm{kg} /$ day ketamine (ketamine) i.p. injection for 30 and 60 days. The product sizes of keratin 6a, 13, 14 and $\beta$-actin are 486, 375, 399 and 623 bp, respectively. (C) Heat map of keratin gene expression. The map was created using the Cluster 3.0. The genes are arrayed from the most downregulated (left) to the most upregulated (right).

\section{Control-60 days}
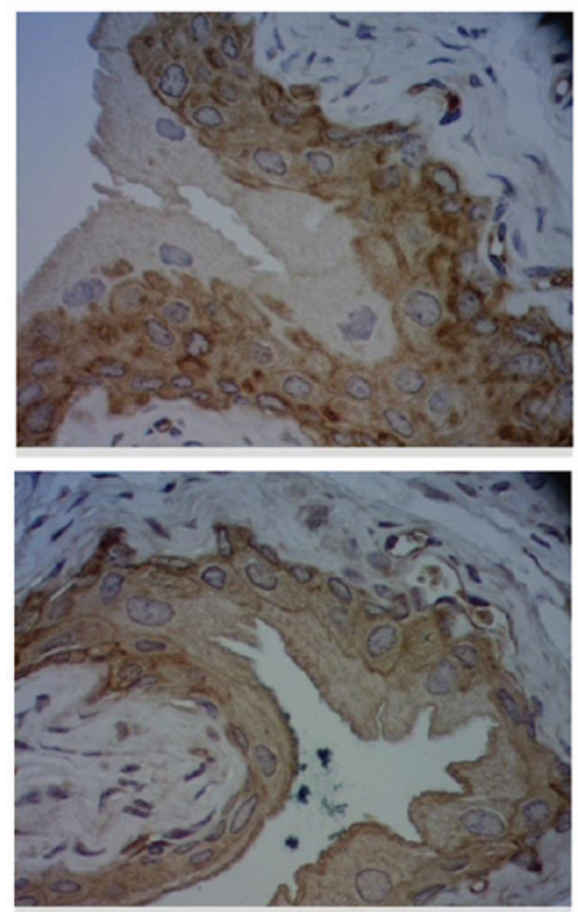

Ketamine-60 days
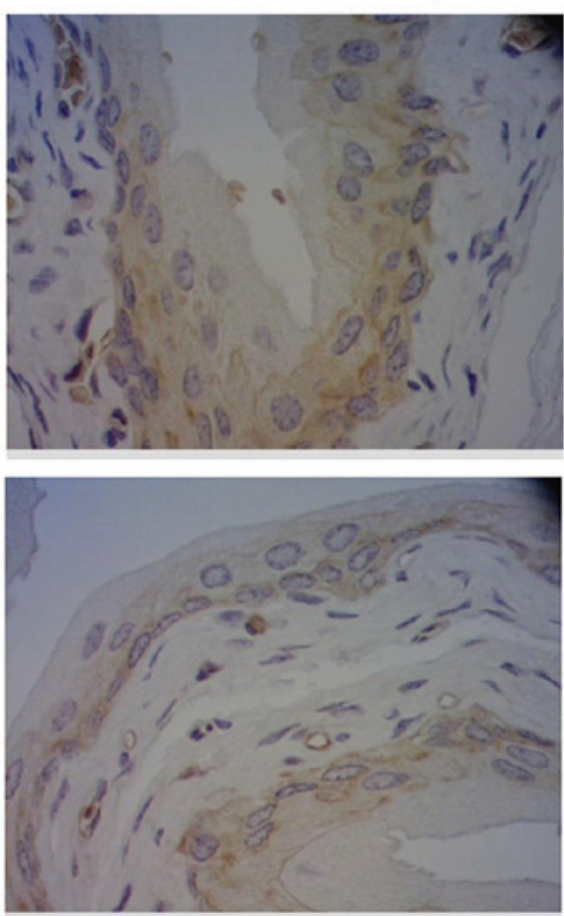

Figure 4. Keratin 14 protein expression in mouse bladder tissues by immunohistochemical analysis. The slides of bladder tissue were hybridized with anti-keratin 14 antibodies and then photographed under x 400 microscopy. Upper and lower images, representative images from two different mouse bladders.

barrier function loss. This suggested that the cytotoxic effect of ketamine may, at least in part, cause the loss of barrier function in ketamine-treated urotheliums.
Effect of daily ketamine injection on mouse body weight, behavior and bladder tissue histology. In addition to the in vitro assay, the present study aimed identify the gene expression in 
Table I. Upregulated genes with differential expression (fold-change $\log 2 \geq 1$ and $\mathrm{P}<0.05$ ) at 60 -day ketamine treatment and statistical difference $(\mathrm{P}<0.05)$ at 30 -day ketamine treatment in mouse bladders.

\begin{tabular}{|c|c|c|c|c|c|c|c|}
\hline \multirow[b]{3}{*}{ Gene name } & \multirow[b]{3}{*}{ Accession number } & \multicolumn{4}{|c|}{ Normalized intensity } & \multirow{2}{*}{\multicolumn{2}{|c|}{$\frac{\text { Ratio of change (\%) }}{(\mathrm{K}-\mathrm{C}) / \mathrm{C} \text { x } 100 \%}$}} \\
\hline & & \multicolumn{2}{|c|}{ 30-day } & \multicolumn{2}{|c|}{ 60-day } & & \\
\hline & & $\mathrm{C}$ & $\mathrm{K}$ & $\mathrm{C}$ & $\mathrm{K}$ & 30-day & 60-day \\
\hline Hedgehog-interacting protein & NM_020259.4 & 296.8 & 602.8 & 183.8 & 847.5 & 103.1 & 361.1 \\
\hline Fucosyl-transferase 9 & NM_010243.3 & 165.3 & 226.6 & 78.2 & 330.7 & 37.1 & 322.9 \\
\hline $\begin{array}{l}\text { Leucine rich repeat containing } \\
\text { G protein coupled receptor } 5\end{array}$ & NM_010195.2 & 97.3 & 143.4 & 149.1 & 435.0 & 47.4 & 191.8 \\
\hline Titin-cap & NM_011540.2 & 264.0 & 501.2 & 282.9 & 741.5 & 89.8 & 162 \\
\hline $\begin{array}{l}\text { Family with sequence } \\
\text { similarity } 55 \text {, member } C\end{array}$ & NM_001134494.1 & 438.0 & 705.3 & 170.4 & 401.8 & 61.0 & 135.8 \\
\hline Toll-like receptor 12 & NM_205823.2 & 127.2 & 263.7 & 131.7 & 306.6 & 107.3 & 132.8 \\
\hline Transthyretin & NM_013697.5 & 8198.6 & 12323.3 & 5331.2 & 11324.8 & 50.3 & 112.4 \\
\hline $\begin{array}{l}\text { Ras-related associated } \\
\text { with diabetes }\end{array}$ & NM_019662.2 & 699.4 & 1682.9 & 427.9 & 836.2 & 140.6 & 95.4 \\
\hline $\begin{array}{l}\text { Transformation related protein } 53 \\
\text { inducible nuclear protein } 1\end{array}$ & $\begin{array}{l}\text { NM_021897.3 } \\
\text { NM_001199105.1 }\end{array}$ & 917.6 & 1624.4 & 528.7 & 1016.2 & 77.0 & 92.2 \\
\hline Claudin 23 & NM_027998.4 & 2564.6 & 3367.4 & 2346.5 & 4466.1 & 31.3 & 90.3 \\
\hline
\end{tabular}

C, control mouse bladders; $\mathrm{K}$, ketamine-injected mouse bladders.

ketamine-treated mouse bladder. Following daily ketamine injection for 30 and 60 days, the growth rate of murine body weight was not significantly different between the control and ketamine-treated group (data not shown). This suggested that intraperitoneal administration of $30 \mathrm{mg} / \mathrm{kg} / \mathrm{day}$ ketamine for 60 days may not affect the physiological properties of the mice. At this dosage, that the mice displayed symptoms of excitation following ketamine injection for 2-5 min, which lasted for $\sim 40$ min. During the injection period, the onset of excitation was gradually delayed and its intensity was also gradually decreased. This suggested that the mice developed a tolerance to ketamine-induced excitation. At the 30th and 60th day, the bladders were isolated for tissue examination. The histology of bladder tissues demonstrated no evident differences between the control and ketamine groups at 30 and 60 days of treatment (data not shown).

Global gene expression analysis in the bladders of ketamine-injected mice. Gene expression microarray analysis of bladder tissue was applied to compare gene expression between the control and ketamine-treated animals. Upregulated genes with differential expression (fold change $\log 2 \geq 1$ and $\mathrm{P}<0.05$ ) at 60 days and a statistical difference (only $\mathrm{P}<0.05$ ) at 30 days were selected. Downregulated genes with differential expression (fold change $\log 2 \leq-1$ and $\mathrm{P}<0.05$ ) at 60 days and statistical difference (only $\mathrm{P}<0.05$ ) at 30 days were selected. Analysis revealed that 10 genes were upregulated (Table I) and 36 genes were downregulated (Table II only reveals the top ten genes and keratin 78). Among these 46 genes, two keratin genes which were associated with cell-cell/basement membrane adhesion function were found to be significantly decreased. Of note, the amount of type I keratin was also decreased in the ketamine-treated rat bladders in the study by $\mathrm{Gu}$ et al (13).

Keratin 14 gene expression is decreased in ketamine-treated mouse bladders. Cytoskeletal keratins belong to intracellular intermediate filaments that connect to epithelial cell adhesion plaques in macula adherens and hemidesmosome sites. Numerous inherited skin-blistering diseases are caused by keratin gene mutations. There were 52 keratin family genes in the gene expression microarray chip. The majority of the keratins were downregulated by ketamine: $40 \%$ following 30 days and $52 \%$ following 60 days (Fig. 3A). The top ten downregulated keratins in the 60-day treatment are listed in Table III. The top three downregulated keratins, including 6a, 13 and 14 were confirmed by PCR analysis (Fig. 3B). Following deleting the genes with no significant difference ( $\mathrm{P}>0.05$ ), a heat map of residue keratin genes was constructed (Fig. 3C). Among the downregulated keratin genes, keratin 14 gene was among the top three genes following 30- and 60-day treatment. Keratin 14 was also among the selected top ten downregulated genes in Table II. To confirm the protein expression change of keratin 14, immunohistochemical analysis was applied. The results demonstrated that keratin 14 protein expression was also decreased in the 60-day murine urothelium (Fig. 4).

\section{Discussion}

In the present in vitro study, it was identified that ketamine damaged urotheliums and decreased barrier function in a 
Table II. Top ten downregulated genes with differential expression (fold change $\log 2 \leq-1$ and $\mathrm{P}<0.05$ ) at 60 -day ketamine treatment and statistical difference $(\mathrm{P}<0.05)$ at 30-day ketamine treatment in mouse bladders.

\begin{tabular}{|c|c|c|c|c|c|c|c|}
\hline \multirow[b]{3}{*}{ Gene name } & \multirow[b]{3}{*}{ Accession number } & \multicolumn{4}{|c|}{ Normalized intensity } & \multirow{2}{*}{\multicolumn{2}{|c|}{$\frac{\text { Ratio of change }(\%)}{(\mathrm{K}-\mathrm{C}) / \mathrm{C} \times 100 \%}$}} \\
\hline & & \multicolumn{2}{|c|}{ 30-day } & \multicolumn{2}{|c|}{ 60-day } & & \\
\hline & & $\mathrm{C}$ & $\mathrm{K}$ & $\mathrm{C}$ & $\mathrm{K}$ & 30-day & 60-day \\
\hline $\begin{array}{l}\text { WAP four-disulfide core } \\
\text { domain } 3\end{array}$ & NM_027961.1 & 102.6 & 46.6 & 528.3 & 59.7 & -54.6 & -88.7 \\
\hline Metallothionein 2 & NM_008630.2 & 1230.5 & 782.7 & 5276.6 & 751.2 & -36.4 & -85.8 \\
\hline $\begin{array}{l}\text { Tissue inhibitor of } \\
\text { metallo-proteinase } 1\end{array}$ & $\begin{array}{l}\text { NM_001044384.1 } \\
\text { NM_011593.2 }\end{array}$ & 1445.2 & 551.3 & 3648.6 & 845.7 & -61.9 & -76.8 \\
\hline Solute carrier family 7 , member 11 & NM_011990.2 & 624.4 & 403.7 & 2992.5 & 708.8 & -35.3 & -76.3 \\
\hline Keratin 14 & NM_016958.1 & 2972.3 & 1652.2 & 6385.7 & 1621.5 & -44.4 & -74.6 \\
\hline $\begin{array}{l}\text { Glutamine fructose-6-phosphate } \\
\text { transaminase } 2\end{array}$ & NM_013529.3 & 329.1 & 224.3 & 806.2 & 211.3 & -31.8 & -73.8 \\
\hline Macrophage scavenger receptor 1 & NM_031195.2 & 457.3 & 283.3 & 891.6 & 281.0 & -38.0 & -68.5 \\
\hline Interleukin 33 & $\begin{array}{l}\text { NM_001164724.1 } \\
\text { NM_133775.2 }\end{array}$ & 1403.7 & 705.9 & 3731.8 & 1207.9 & -49.7 & -67.6 \\
\hline $\begin{array}{l}\text { C-type lectin domain family } 4 \text {, } \\
\text { member d }\end{array}$ & $\begin{array}{l}\text { NM_00116316.1 } \\
\text { NM_010819.4 }\end{array}$ & 151.6 & 73.6 & 201.6 & 66.5 & -51.5 & -67.0 \\
\hline Neuregulin 1 & NM_178591.2 & 86.5 & 49.5 & 199.8 & 68.0 & -42.8 & -66.0 \\
\hline Keratin 78 & NM_212487.4 & 241.5 & 166.6 & 857.4 & 365.9 & -31.0 & -57.3 \\
\hline
\end{tabular}

C, control mouse bladders; K, ketamine-injected mouse bladders.

Table III. Top ten downregulated keratin genes following ketamine treatment for 60 days .

\begin{tabular}{|c|c|c|c|c|c|c|c|}
\hline \multirow[b]{3}{*}{ Gene name } & \multirow[b]{3}{*}{ Accession number } & \multicolumn{4}{|c|}{ Normalized intensity } & \multirow{2}{*}{\multicolumn{2}{|c|}{$\begin{array}{r}\text { Ratio of change }(\%) \\
(\mathrm{K}-\mathrm{C}) / \mathrm{Cx} 100 \%\end{array}$}} \\
\hline & & \multicolumn{2}{|c|}{ 30-day } & \multicolumn{2}{|c|}{ 60-day } & & \\
\hline & & $\mathrm{C}$ & $\mathrm{K}$ & $\mathrm{C}$ & $\mathrm{K}$ & 30-day & 60-day \\
\hline Keratin $6 a$ & NM_008476.3 & 42.6 & 24.3 & 985.4 & 46.0 & -43.0 & $-95.3^{\mathrm{a}}$ \\
\hline Keratin 13 & NM_010662.1 & 130.9 & 170.0 & 1165.9 & 181.6 & 29.9 & $-84.4^{\mathrm{a}}$ \\
\hline Keratin 14 & NM_016958.1 & 2972.3 & 1652.2 & 6385.7 & 1621.5 & $-44.4^{\mathrm{a}}$ & $-74.6^{\mathrm{a}}$ \\
\hline Keratin 23 & NM_033373.1 & 580.3 & 676.9 & 1926.2 & 722.6 & 16.6 & $-62.5^{\mathrm{a}}$ \\
\hline Keratin 78 & NM_212487.4 & 241.5 & 166.6 & 394.9 & 185.3 & $-31^{\mathrm{a}}$ & $-57.3^{\mathrm{a}}$ \\
\hline Keratin 5 & NM_027011.2 & 6344.0 & 6327.0 & 9821.2 & 5129.2 & -0.3 & $-47.8^{\mathrm{a}}$ \\
\hline Keratin $6 b$ & NM_010669.2 & 13.9 & 9.5 & 35.5 & 19.9 & (NA) & -44 \\
\hline Keratin 8 & NM_031170.2 & 13729.3 & 15504.3 & 20223.6 & 13109.0 & 12.9 & $-35.2^{\mathrm{a}}$ \\
\hline Keratin 19 & NM_008471.2 & 9891.2 & 7572.7 & 15246.7 & 10048.5 & -23.4 & $-34.1^{\mathrm{a}}$ \\
\hline Keratin 79 & NM_146063.1 & 104.4 & 100.4 & 163.7 & 108.2 & -3.9 & $-33.9^{\mathrm{a}}$ \\
\hline
\end{tabular}

${ }^{a} \mathrm{P}<0.05$, indicates a significant difference between the control and ketamine-injected groups. Rosetta Resolver ${ }^{\circledR}$ was applied to detect signal noise for reducing the false positive, the signal was adjusted to NA if this sample was not qualified. C, control mouse bladders; K, ketamine-injected mouse bladders.

dose-dependent manner. In the in vivo mouse study, it was demonstrated that ketamine decreased the expression of numerous keratin genes, including keratin 14. Keratin 14 protein is also decreased in ketamine-treated mouse bladders.
This suggested that cytotoxicity may cause the loss of urothelial barrier function at high doses of ketamine, while at low doses, keratin gene downregulation may be a sign of urothelial disorder. 
Table IV. Four gene expression change data in normal saline and ketamine treatment for 30 and 60 days.

\begin{tabular}{|c|c|c|c|c|c|c|c|}
\hline \multirow[b]{3}{*}{ Gene name } & \multirow[b]{3}{*}{ Accession number } & \multicolumn{4}{|c|}{ Normalized intensity } & \multirow{2}{*}{\multicolumn{2}{|c|}{$\frac{\text { Ratio of change }(\%)}{(\mathrm{K}-\mathrm{C}) / \mathrm{Cx} 100 \%}$}} \\
\hline & & \multicolumn{2}{|c|}{ 30-day } & \multicolumn{2}{|c|}{ 60-day } & & \\
\hline & & $\mathrm{C}$ & $\mathrm{K}$ & $\mathrm{C}$ & $\mathrm{K}$ & 30-day & 60-day \\
\hline Integrin $\alpha 6$ & NM_008397.3 & 6661.3 & 9441.9 & 9028.3 & 7893.3 & $41.7^{\mathrm{a}}$ & -12.6 \\
\hline Integrin $\beta 4$ & $\begin{array}{l}\text { NM_133663.2 } \\
\text { NM_001005608.2 }\end{array}$ & 802.7 & 739.2 & 1082.0 & 394.7 & -7.9 & $-63.5^{\mathrm{a}}$ \\
\hline Claudin-1 & NM_016674.4 & 1146.1 & 1002.7 & 3597.1 & 1209.6 & -12.5 & $-66.4^{\mathrm{a}}$ \\
\hline Keratin 20 & NM_023256.1 & 473.0 & 568.4 & 1954.1 & 708.4 & 20.2 & $-63.7^{\mathrm{a}}$ \\
\hline
\end{tabular}

${ }^{\mathrm{a}}<0.05$ between the control and ketamine-injected groups. $\mathrm{C}$, control mouse bladders; $\mathrm{K}$, ketamine-injected mouse bladders.

Ketamine demonstrated toxicity (Fig. 1A) and induced sub-G1 formation in a dose- and time-dependent manner (Fig. 1B-D). Therefore, it may be concluded that highly frequent and repeated doses of ketamine may eventually cause urothelial damage in abusive, recreational users. The cytotoxicity of ketamine has been reported in neuroblastoma $(17,18)$, lymphoma Jurkat cells (18) and hepatoma (19). In these three studies, it was collectively suggested that ketamine induced cell death via apoptosis and urothelial apoptosis was also found in abusers (20). In addition, the present study also analyzed the barrier function of urotheliums in vitro. The results indicated that ketamine also increased barrier permeability in a dose-dependent manner (Fig. 2).

According to Yeung's ICR mouse model $(30 \mathrm{mg} / \mathrm{kg} /$ day for 1 and 3 months) (11), ketamine injection induces urothelial degeneration and inflammatory cell infiltration in bladders. In the present study, the same dose of ketamine was used in Balb/c mice, and no inflammatory phenomenon was observed by histological examination. Four inflammatory genes (cyclooxygenase-2, nitric oxide synthase-2, interleukin-6 and -10) from microarray data were selected for analysis by PCR and no visual PCR products were observed on the gel (data not shown). This result suggested that inflammation had not yet occurred in the Balb/c mouse bladder tissue following $30 \mathrm{mg} / \mathrm{kg} /$ day ketamine treatment for 30 and 60 days. These data were consistent with the result of the histological analysis, using H\&E staining, which demonstrated no inflammatory cell infiltration in the bladder tissue. In Meng's mouse model (100 mg/kg/day for 1 to 4 months) (12), another mouse strain C57BL/6 was used with higher ketamine dosages. The authors identified that ketamine reduced the mouse weight growth and induced micturition following eight weeks. The bladder histology also demonstrated urothelial degeneration and mononuclear cell infiltration, while submucosal congestion was not present in Yeung's results. These results suggested that the strain and ketamine dose may affect the level of ketamine-induced bladder disorder. In addition to strain and ketamine dosage, gender may be another reason for differences at the damage level. The same strain of Sprague-Dawley rats but a different gender was used in Gu et al's study (50 mg/kg/day for 16 weeks, male rats) (13) and Chaung et al's study (25 mg/kg/day for four weeks, female rats) (14).
According to Gu et al's study, ketamine increased the urinary frequency and induced hematuria, hyperplastic epithelium and inflammatory cell infiltration in the bladder (13). By contrast, according to Chaung et al's study, using a lower ketamine dose and short treatment time, ketamine induced urothelial degeneration, red blood cell debris accumulation in bladder cavity and mononuclear cell infiltration. The urothelial mucosal damage of female rats appeared to be more severe than that of male rats.

Keratins are the major component of the fibrous intermediate filament in epithelial cells. Keratin 20 is a tumor marker of urothelial dysplasia (21). One study found that keratin 20 expression decreased in the bladder of ketamine-abusing individuals (22). The microarray data of the present study also indicated that keratin 20 decreased within 60 days (Table IV). Different keratins are expressed in different layers of the urothelium (basal, intermediate and umbrella), keratin 20 is in the umbrella layer and keratin 14 is in the basal/intermediate layers (23). Keratin 14 and 5, type I and type II keratins, assemble to heterodimers, and thousands of them assemble to 10-nm-wide intermediate filament cytoskeleton. According to the present study, keratin 5 was also decreased in the bladders of ketamine-treated mice. Mutations in keratin 14 or keratin 5 cause a rare genetic disease called epidermolysis bullosa simplex (24). In addition to the representative skin bullous lesions, patients with epidermolysis bullosa simplex also demonstrated fragility of epithelial tissues in the genitourinary tract, which caused voiding difficulty and urinary retention (25). The cell proliferation rate was reduced following knockdown of keratin 14 (26). It remains elusive whether or not the downregulation of keratin genes induces urinary disorders in ketamine abusers, and therefore, it is worthy of further study.

In addition to decreases in the levels of various types of keratin, the cDNA array data indicated further mechanisms leading to the downregulation of urothelial barrier function. Firstly, the hemidesmosome, consisting of intracellular keratins, plectin plaque and adhesion molecules, such as the $\alpha 6 \beta 4$ integrin (27), contributed to the firm attachment between urothelium and extracellular matrix. In the array data, integrin $\alpha 6 / \beta 4$ demonstrated a marked decrease as well at 60 days (Table IV), which may implicate the hemidesmosome was 
collapsing and cell is progressively denuding from basal lamina. Secondly, it was identified the claudin-1 expression was also downregulated at 60 days (Table IV). This suggested that tight junctions of the urothelium may also have been affected. Although bladder damages were not identified in the $30 \mathrm{mg} / \mathrm{kg} /$ day ketamine-treated Balb/c mice, the microarray data demonstrated certain molecular defects which correlated with urothelial barrier function. Additional studies are required to further elucidate these correlations.

\section{Acknowledgements}

This study was supported by grants from the National Science Council of Taiwan (NSC101-2320-B-415-002-MY3) and from Chiayi Christian Hospital, Taiwan (R100-9).

\section{References}

1. Domino EF, Chodoff P and Corssen G: Pharmacologic effects of Ci-581, a new dissociative anesthetic, in man. Clin Pharmacol Ther 6: 279-291, 1965.

2. Sinner B and Graf BM: Ketamine. Handb Exp Pharmacol: 313-333, 2008.

3. Ivani G, Vercellino C and Tonetti F: Ketamine: a new look to an old drug. Minerva Anestesiol 69: 468-471, 2003.

4. Domino EF: Taming the ketamine tiger. 1965. Anesthesiology 113 678-684, 2010.

5. Chu PS, Kwok SC, Lam KM, et al: 'Street ketamine'-associated bladder dysfunction: a report of ten cases. Hong Kong Med J 13: 311-313, 2007.

6. Shahani R, Streutker C, Dickson B and Stewart RJ Ketamine-associated ulcerative cystitis: a new clinical entity. Urology 69: 810-812, 2007.

7. Ng SH, Tse ML, Ng HW and Lau FL: Emergency department presentation of ketamine abusers in Hong Kong: a review of 233 cases. Hong Kong Med J 16: 6-11, 2010.

8. Tsai TH, Cha TL, Lin CM, et al: Ketamine-associated bladder dysfunction. Int J Urol 16: 826-829, 2009.

9. Middela $S$ and Pearce I: Ketamine-induced vesicopathy: a literature review. Int J Clin Pract 65: 27-30, 2011.

10. Chen CH, Lee MH, Chen YC and Lin MF: Ketamine-snorting associated cystitis. J Formos Med Assoc 110: 787-791, 2011.

11. Yeung LY, Rudd JA, Lam WP, Mak YT and Yew DT: Mice are prone to kidney pathology after prolonged ketamine addiction. Toxicol Lett 191: 275-278, 2009.
12. Meng E, Chang HY, Chang SY, et al: Involvement of purinergic neurotransmission in ketamine induced bladder dysfunction. J Urol 186: 1134-1141, 2011

13. Gu D, Huang J, Shan Z, et al: Effects of long-term ketamine administration on rat bladder protein levels: a proteomic investigation using two-dimensional difference gel electrophoresis system. Int J Urol 20: 1024-1031, 2013.

14. Chuang SM, Liu KM, Li YL, et al: Dual involvements of cyclooxygenase and nitric oxide synthase expressions in ketamine-induced ulcerative cystitis in rat bladder. Neurourol Urodyn 32: 1137-1143, 2013.

15. Rigby CC and Franks LM: A human tissue culture cell line from a transitional cell tumour of the urinary bladder: growth, chromosone pattern and ultrastructure. Br J Cancer 24: 746-754, 1970

16. Fogh J, Fogh JM and Orfeo T: One hundred and twenty-seven cultured human tumor cell lines producing tumors in nude mice. J Natl Cancer Inst 59: 221-226, 1977.

17. Mak YT, Lam WP, Lu L, Wong YW and Yew DT: The toxic effect of ketamine on SH-SY5Y neuroblastoma cell line and human neuron. Microsc Res Tech 73: 195-201, 2010.

18. Braun S, Gaza N, Werdehausen R, et al: Ketamine induces apoptosis via the mitochondrial pathway in human lymphocytes and neuronal cells. Br J Anaesth 105: 347-354, 2010

19. Lee ST, Wu TT, Yu PY and Chen RM: Apoptotic insults to human HepG2 cells induced by S-(+)-ketamine occurs through activation of a Bax-mitochondria-caspase protease pathway. Br J Anaesth 102: 80-89, 2009.

20. Lee CL, Jiang YH and Kuo HC: Increased apoptosis and suburothelial inflammation in patients with ketamine-related cystitis: a comparison with non-ulcerative interstitial cystitis and controls. BJU Int 112: 1156-1162, 2013.

21. Harnden P, Eardley I, Joyce AD and Southgate J: Cytokeratin 20 as an objective marker of urothelial dysplasia. Br J Urol 78: 870-875, 1996

22. Oxley JD, Cottrell AM, Adams S and Gillatt D: Ketamine cystitis as a mimic of carcinoma in situ. Histopathology 55: 705-708, 2009.

23. Castillo-Martin M, Domingo-Domenech J, Karni-Schmidt O, Matos T and Cordon-Cardo C: Molecular pathways of urothelial development and bladder tumorigenesis. Urol Oncol 28: 401-408, 2010.

24. Coulombe PA, Kerns ML and Fuchs E: Epidermolysis bullosa simplex: a paradigm for disorders of tissue fragility. J Clin Invest 119: 1784-1793, 2009.

25. Arifi M, Arifi S, Demni K, et al: Genitourinary complications as initial presentation of inherited epidermolysis bullosa. Afr J Paediatr Surg 8: 72-74, 2011.

26. Alam H, Sehgal L, Kundu ST, Dalal SN and Vaidya MM: Novel function of keratins 5 and 14 in proliferation and differentiation of stratified epithelial cells. Mol Biol Cell 22: 4068-4078, 2011.

27. Mercurio AM: Laminin receptors: achieving specificity through cooperation. Trends Cell Biol 5: 419-423, 1995. 